\title{
More Minimally Invasive Percutaneous Nephrolithotomy in Adult Patients with Kidney Stones
}

\section{Erișkin Böbrek Tașı Hastalarında Daha Minimal İnvazif Perkütan Nefrolitotomi}

\author{
Bülent KATI ${ }^{1}(\mathbb{D})$, Adem TUNÇEKIN ${ }^{1}(\mathbb{D})$, ibrahim Halil ALBAYRAK ${ }^{1}$ \\ Muhammed Nur KARADENiz ${ }^{1}$ (D) Halil ÇifTÇi $^{1}$
}

${ }^{1}$ Harran University, Faculty of Medicine, Department of Urology, Şanlıurfa, TURKEY

\section{Abstract}

Background: Percutaneous nephrolithotomy (PCNL) is a minimally invasive surgical procedure recommended to remove kidney stones larger than $2 \mathrm{~cm}$. Miniaturized nephroscopes developed over the years to treat pediatric kidney stones have been increasingly used in surgeries referred to as mini PCNL (MPCNL). This study will evaluate the success rates and results of $\mathrm{MPCNL}$ operations performed on adult patients.

Materials and Methods: The study will examine MPCNL (20-24f) performed in the prone position on adults over 18 years old with kidney stones between January 2018 and June 2020. Further, the pre-operative (pre-op) and post-operative (post-op) features of 42 patients were retrospectively evaluated. The patients' features, including post-op stone-free status and complications, were determined and included in the research.

Results: The mean age of the patients was $33.64 \pm 6.8$ years, and $18(42.8 \%)$ of them had at least grade 1 hydronephrosis. The average stone size was $300 \pm 26 \mathrm{~mm}^{2}$. Three (7.1\%) patients had a "staghorn" type stone. The mean operation time was $52 \pm 18$ minutes and post-op stone-free rate was present in $33(78.5 \%)$ patients. Additionally, post-op blood transfusions were provided to three (7.1\%) patients. Tubeless PCNL was not applied to any patients. After the removal of the nephrostomy tubes, double-J stents were placed in four (9.5\%) patients for drainage and in another due to postoperative pyelonephritis. The average length of time a nephrostomy tube was used on patients was $2.5 \pm 0.6$ days.

Conclusions: $\mathrm{MPCNL}$ should be one of the first options for resolving ureteral obstructions in adult patients with a high risk of bleeding or co-morbidities from the operation. Thus, it is a more reliable option that can be used to reduce the risk of complications.

Key Words: PCNL, Mini PCNL, Kidney Stones, Complications

Öz.

Amaç: Perkütan nefrolitotomi (PNL) ameliyatı 2 cm'den büyük böbrek taşları için önerilen minimal invazif bir cerrahi işlemdir. Yıllar içinde pediatrik böbrek taşları için geliştirilen minyatürize nefroskoplar artan bir hızla cerrahide mini PNL tanımını alarak uygulanmıştır. Bu çalışmada erişkin hastalara uyguladığımı mPNL operasyonlarının başarı ve sonuçlarını değerlendirdik.

Materyal ve Metod: Ocak 2018-Haziran 2020 tarihleri arası hastanemizde 18 yaş üstü erişkin böbrek taşlarına pron pozisyonda uyguladığımız mPNL (20-24f), 42 hasta pre op ve post op özellikleri ile beraber retrospektif olarak değerlendirildi. Hasta özellikleri, operasyon sonrası taşsızlık durumu ve post op komplikasyonlar belirlenerek çalışmaya eklendi.

Bulgular: Hastaların yaş ortalaması 33,64 \pm 6.8 yıldı. Hastaların $18^{\prime}$ inde $(\% 42.8)$ en az grade 1 hidronefroz mevcuttu. Ortalama taş boyutu $300 \pm 26$ mm2'di. Üç (\%7.1) hastada "staghorn" tipi taş mevcuttu. Ortalama operasyon zamanı $52 \pm 18 \mathrm{dk}$ 'di. Operasyon sonrası taşsızık oranı $33(\% 78,5)$ hastada mevcuttu. Post op toplam 3 (\%7.1) hastaya ek kan desteği sağlandı. Tüpsüz PNL uygulanmadı. Nefrostomi çıkarılması sonrası akıtma nedeniyle 4 (\%9.5) hastaya ve post operatif piyelonefrit tablosu gelişen bir hastaya JJ stent takıldı. Ortalama nefrostomi kalıs zamanı $2,5 \pm 0,6$ gündü.

Sonuç: $\mathrm{MPNL}$ özellikle pre-post operatif komplikasyonların daha az ve düzeltilebilir olması nedeniyle kanama riski veya operasyon için ko-morbiditesi olan erişkin hastalarda akut obstruksiyonu açmak amaçlı ilk seçeneklerden olabileceğini önermekteyiz.

Anahtar kelimeler: PNL, Mini PNL, Böbrek Taşı, Komplikasyon
Sorumlu Yazar/Corresponding Author

Dr. Bülent KATI

Harran University, Faculty of

Medicine,

Urology Department. Osmanbey

Kampusu

Şanlıurfa/TURKEY

E-mail: bulentkati@harran.edu.tr

Geliş tarihi / Received: 30.04 .2021

Kabul tarihi / Accepted: 09.07.2021

DOI: $10.35440 /$ hutfd.930444

This study was presented as an ora presentation at the 1-4 April 2021 National Endourology Congress (online). 


\section{Introduction}

Minimally invasive percutaneous nephrolithotomy (mPCNL) was developed for the treatment of pediatric patients with kidney stones. Generally, the technique is defined by the use of 18-24 $\mathrm{F}$ renal sheaths that produce an enlargement of the skin of approximately $6-8 \mathrm{~mm}(1,2)$. Early case studies found that stone clearance rates were equivalent to traditional PCNL results, with the benefit of reduced hemorrhages. However, $\mathrm{MPCNL}$ has been met with skepticism and has reportedly not met expectations. Because it was thought that it might prolong the operation time and cause additional complications. (3). Later clinical use and further case studies indicate that a modified standard mPCNL with smaller percutaneous dilatation (14-24 F) has proven to be a safe and minimally invasive effective treatment for both pediatric and adult patients (4-5). This study aims to evaluate the success rates and complications of mPCNL operations performed on suitable adult patients.

\section{Materials and Methods}

After the approval of the ethics committee (Harran Unv. 15.03.2021. HRU 21/06/17), 42 patients aged 18 years and over who had $\mathrm{mPCNL}$ operations at the university hospital between January 2018 and June 2020 were retrospectively evaluated. This study was conducted in accordance with the Helsinki Declaration 2008 principles. The gender, age, stone, and urinary tract infection status of each patient was evaluated. Direct urinary system radiography (DUSG), urinary ultrasonography (USG), intravenous pyelography (IVP) when necessary, and non-contrast spiral computed tomography (CT) were recorded in all patients. Pre-op prophylactic antibiotics were also administered to all patients. Stone size was determined as $\mathrm{mm}^{2}$ by multiplying the longest edge of the stone with the edge perpendicular to it according to a direct graph. Laboratory and radiological examinations were evaluated to determine stone location, stone burden, postoperative nephrostomy use, complications, and treatment results. Since the whole body was exposed to radiation, the places outside the kidney area were covered with a lead shirt and a lead protective shirt was laid on the table, as the beam was coming from below.

The procedure applied to all patients was administered with a cystoscope in the lithotomy position. A 5F or 6F ureter catheter was placed on the side the operation was planned for, and the patient was placed in the prone position. Biplanar 18 Gauge Chiba needle was used accompanied by fluoroscopy. A 0.038 -inch hydrophilic guidewire was advanced from the entry site using the triangulation technique and was dilated up to 20-24 F. In addition, a second non-hydrophilic guidewire was sent to the collector system for safety, and the working sheath, which could be between 20-24 F, was placed in the pelvicalyceal system (Figure 1). The stone was reached with a $17 \mathrm{~F}$ rigid nephroscope. The kidney stone was then broken with a pneumatic lithotriptor and removed with the help of stone forceps. The irrigation fluid used during the procedure was not cold and was applied with low pressure. At the end of the operation, a 12-14 F Petzer catheter was used as a nephrostomy tube. Postoperative complications were evaluated according to the Clavien classification (6). Stones larger than $4 \mathrm{~mm}$ were considered significant residual stones, and those smaller than $4 \mathrm{~mm}$ were considered clinically insignificant residual fragments in computer tomography (CT). As the evaluation was made after the conclusions were drawn, additional statistical study or comparison was not conducted.

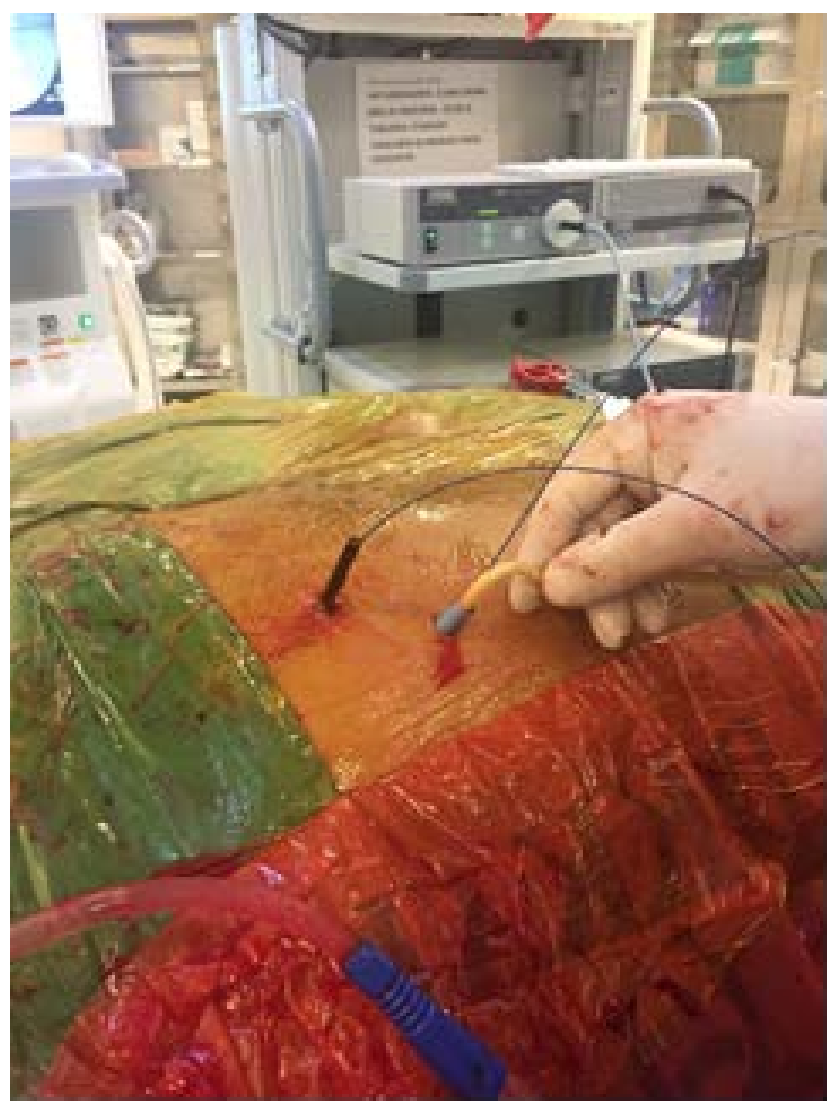

Figure 1. Placement of renal sheaths, guides and nephrostomy tube in prone position in $\mathrm{MPCNL}$.

\section{Statistical Analysis}

Data collection was performed using IBM SPSS 20.0 (IBM Inc., Chicago, IL, USA). The conformity of the variables to the normal distribution was determined by the ShapiroWilk test, and the variables with normal distribution were presented as mean \pm standard deviation. Differences between groups were analyzed using an independent sample t-test. Categorical variables were presented as frequency and percentage and compared with the chi-square test.

\section{Results}

Of the 42 patients treated with an MPCNL operation, 15 were female and 27 were male. The average age was 33.64 
\pm 6.8 years. The right side $\mathrm{mPCNL}$ was applied to 20 of the patients, and the left side was applied to 22 patients. Four of the patients had bilateral kidney stones. There was no bilateral application. Six patients with positive urine cultures were treated according to the results of the antibiograms. They were operated on when their urine culture was sterile. Renal dysfunction was not detected in the patients' laboratory tests. Additionally, 18 (42.8\%) of the patients had at least grade 1 hydronephrosis. Nine patients (21.4\%) received medical stone treatment. Eight (19\%) patients had a previous history of ESWL. Further, 12 (28.5\%) patients had previously been treated for infection. Average stone size was $300 \pm 26 \mathrm{~mm} 2$. Three (7.1\%) patients had a "staghorn" type stone. Mean operation time was 52 \pm 18 minutes. Postoperative stone-free rate was present in $33(78.5 \%)$ patients. Additional blood transfusion was provided to $3(7.1 \%)$ patients postoperatively. Tubeless mPCNL was not applied. After nephrostomy removal, JJ stents were placed in $4(9.5 \%)$ patients due to urine leak and one patient with postoperative pyelonephritis. The mean time of nephrostomy stay was $2.5 \pm 0.6$ days (Table I).

Table 1. General Characteristics of MPCNL Patients

\begin{tabular}{|l|c|}
\hline Patients & $\mathbf{4 2}(\% 100)$ \\
\hline Mean age (years) & $33,64 \pm 6.8$ \\
\hline Right side mPCNL number & $20(\% 47,6)$ \\
\hline Left side mPCNL number & $22(\% 52,3)$ \\
\hline Stone-free rate & $33(\% 78,6)$ \\
\hline Stone residue & $9(\% 21,4)$ \\
\hline Blood transfusion requirement & $3(\% 17,1)$ \\
\hline Post op JJ stent requirement & $4(\% 9,5)$ \\
\hline $\begin{array}{l}\text { Patients who spontaneously passed stones } \\
\text { during controls }\end{array}$ & $3(\% 7,1)$ \\
\hline $\begin{array}{l}\text { Postoperative ESWL patient (among those } \\
\text { with residual stones) }\end{array}$ & $5(\% 11,9)$ \\
\hline Hemoglobine decrease & $1 \pm 0,3 \mathrm{~g} / \mathrm{dL}$ \\
\hline Stone localization & $19(\% 45)$ \\
\hline Inferior calix stone & $8(\% 19)$ \\
\hline Pelvic stone & $7(\% 16,5)$ \\
\hline Inferıor calix +Pelvic stone & $5(\% 11,9)$ \\
\hline Middle calix -Pelvic stones & $3(\% 7,1)$ \\
\hline "Staghorn" style stone &
\end{tabular}

\section{Discussion}

Bleeding during and after surgery is the most common complication of PCNL and may require blood transfusion, however, it is a concern for urologists and less invasive options are tried first. Among these, extracorporeal shock wave lithotripsi (ESWL) and retrograde intrarenal surgery (RIRS) are frequently used with low and manageable complication rates. Although $\mathrm{mPCNL}$ has been used for surgical purposes in pediatric stone patients for years, it has become an alternative for kidney stones that may pose a risk for adult patients (7). This is an advantage over retrograde intrarenal surgery (RIRC), where the rate of failed access can be up to $15 \%$. Thus, it eliminates the risk of ureteral damage, either alone or with the use of an access sheath (8). With the increase in the use of $\mathrm{m}-\mathrm{PCNL}$ in recent years, there has been a proportional decrease in the use of postoperative ureteral drainage with a double J stent. Studies are now reporting an increase in completely tubeless surgery. Overall, PCNL complication rates were $20-22 \%$, while a study found that the overall complication rate in $\mathrm{MPCNL}$ was less than in standard PCNL (15.2\% mPCNL). These complications are predominantly low grade as expected and any Clavien IV / V complications have not been recorded. PCNL access with optical needle theoretically provides to avoid injury of the renal parenchyma and other internal organs. This method also allows a one-step process for renal access and therefore reduces lithotripsy startup time (9). In our study, the time for reaching and lithotripsy to the kidney stone was shorter due to the dilatation time decreased. Experience with standard PCNL (26-30F) surgery recommends switching to smaller instruments, especially for stones between 1 and $2.5 \mathrm{~cm}$, and studies indicate better intraoperative surgeon comfort using $\mathrm{mPCNL}$ techniques (10). MPCNL has a significant advantage over standard PCNL in reducing bleeding, providing a higher chance of resulting in tubeless surgery (75$80 \%$ ) and a shorter hospital stay (2.43-4.5 days as studies have shown) (11). The longer surgery time was thought to depend on the size and type of the stone. Laser lithotripsy is effective in breaking up stones, but it has been shown to take longer than pneumatic lithotripsy (12). While evaluating the results of $\mathrm{MPCNL}$, we determined that it causes fewer complications in terms of bleeding compared to standard PNL.

While the difference in hemoglobin $(\mathrm{Hb})$ decrease in our previous standard PNL controls was $1.3 \mathrm{~g} / \mathrm{dL}$, we observed that it was approximately $1 \mathrm{~g} / \mathrm{dL}$ after mPCNL. We did not apply tubeless $\mathrm{MPCNL}$. However, the ureteral catheter indwelling time ( $2.5 \pm 0.6$ days) was shorter. (13). There was no difference in general complications between $\mathrm{mPCNL}$ and SPCNL. Untreated preoperative urinary tract infection, high perfusion pressure, longer operative time, toxin absorption and perforation of the pelvicalyceal system, and poor postoperative pelvicalyceal system drainage are thought to be responsible for the increase in complications (14). According to the clinical results mentioned in our other studies, there was no significant difference between $\mathrm{mPCNL}$ and SPCNL in terms of overall complications (13). The nephrostomy tube placed at the end of the procedure has many advantages. The nephrostomy tube provides uninterrupted urinary drainage, provides the kidney access tract and provides a second view, which is very important in the buffer functions of the kidney. Tubeless PNL has advantages such as less postoperative pain and early discharge (15). We did not perform any tubeless procedure after our $\mathrm{mPCNL}$, but we aimed to reduce the postoperative pain by removing the nephrostomy tubes early in suitable patients.

Today, it is thought that invasive stone surgery will turn into more minimal surgery with the development of pow- 
erful laser and suitable flexible mini-instruments. We anticipate that the MPCNL procedure will become standard in order to avoid a possible major complication in widespread use. We recommend $\mathrm{mPCNL}$ as one of the first options, especially in adults with impaired renal function or with solitary kidneys and have high bleeding risk and serious comorbidities in terms of additional surgery or anesthesia.

Ethical Approval: Ethical approval was obtained for the study from the Harran University Faculty of Medicine Clinical Research Ethics Committee (dated 15.03.2021, HRU/21/06/17).

\section{Author Contributions:}

Concept: B.K. A.T

Literature Review: B.K. A.T. I.H.A.

Design : M.N.K. H.Ç.

Data acquisition: A.T. I.H.A.

Analysis and interpretation: B.K. H.Ç.

Writing manuscript: B.K. A.T.

Critical revision of manuscript: B.K. H.Ç.

Conflict of Interest: The authors declared no conflict of interest Financial Disclosure: The authors declared that they did not receive any financial support for this study

\section{References}

1. D'Arcy FT, Lawrentschuk N, Manecksha RP, Webb DR. Renal track creation for percutaneous nephrolithotomy: the history and relevance of single stage dilation. Can J Urol. 2015 Oct;22(5):7978-83.

2. Webb DRTH. Intraluminal surgery of the uper tract. Dial Paed Urol first edition, USA 1995;18: 2-4

3. Giusti G, Piccinelli A, Taverna G, Benetti A, Pasini L, Corinti M, et al. Miniperc? No, thank you! Eur Urol. 2007 Mar;51(3):810-4.

4. Salah MA, Tóth C, Khan AM, Holman E. Percutaneous nephrolithotomy in children: experience with 138 cases in a developing country. World J Urol. 2004 Oct;22(4):277-80.

5. Samad L, Aquil S, Zaidi Z. Paediatric percutaneous nephrolithotomy: setting new frontiers. BJU Int. 2006 Feb;97(2):35963.

6. Dindo D, Demartines N, Clavien PA. Classification of surgical complications: a new proposal with evaluation in a cohort of 6336 patients and results of a survey. Ann Surg. 2004 Aug;240(2):205-13.

7. Jones $P$, Elmussareh $M$, Aboumarzouk OM, Mucksavage $P$, Somani BK. Role of Minimally Invasive (Micro and Ultra-mini) PCNL for Adult Urinary Stone Disease in the Modern Era: Evidence from a Systematic Review. Curr Urol Rep. 2018 Mar 7;19(4):27.

8. Schoenthaler $M$, Wilhelm $K$, Hein $S$, Adams $F$, Schlager $D$, Wetterauer $\mathrm{U}$, et al. Ultra-mini PCNL versus flexible ureteroscopy: a matched analysis of treatment costs (endoscopes and disposables) in patients with renal stones 1020mm. World J Urol. 2015;33(10):1601-5.

9. Jones $P$, Bennett $G$, Aboumarzouk OM, Griffin S, Somani BK. Role of Minimally Invasive Percutaneous Nephrolithotomy Techniques-Micro and Ultra-Mini PCNL $(<15 F)$ in the Pediatric Population: A Systematic Review. J Endourol. 2017 Sep;31(9):816-824.
10. Sabnis RB, Ganesamoni R, Ganpule AP, Mishra S, Vyas J, Jagtap J et al. Current role of microperc in the management of small renal calculi. Indian J Urol. 2013 Jul;29(3):214-8.

11. Thapa BB, Niranjan V. Mini PCNL Over Standard PCNL: What Makes it Better? Surg J (N Y). 2020 Feb 12;6(1):e19-e23.

12. Ganesamoni R, Sabnis RB, Mishra S, Parekh N, Ganpule A, Vyas JB et al. Prospective randomized controlled trial comparing laser lithotripsy with pneumatic lithotripsy in miniperc for renal calculi. J Endourol. 2013 Dec;27(12):1444-9.

13. Kati B, Buyukfirat E, Pelit ES, Yagmur I, Demir M, Albayrak IH, Ciftci H. Percutaneous Nephrolithotomy with Different Temperature Irrigation and Effects on Surgical Complications and Anesthesiology Applications. J Endourol. 2018 Nov;32(11):1050-1053.

14. Lahme S. Miniaturisation of PCNL. Urolithiasis. 2018 Feb;46(1):99-106.

15. Sebaey A, Khalil MM, Soliman T, Mohey A, Elshaer W, Kandil $W$ et al. Standard versus tubeless mini-percutaneous nephrolithotomy: A randomised controlled trial. Arab J Urol. 2016 Mar;14(1):18-23. 